\title{
The histological effects of vitamin A supplement on the vaginal epithelial cells during estrus and luteal phases in Awassi sheep
}

A. M. Hussin

Coll. of Vet. Med/ Univ of Baghdad.

\section{Abstract}

This study was carried out on the vaginal epithelium of eight Awassi ewes during estrus and luteal phases in order to evaluate the histological effect of vitamin A on the vaginal epithelium, vaginal smears were taken and stained by methylene blue. Light microscope was used in examination of slides. The present result revealed that vitamin A stimulated the process of keratinization which in turn raised the immune response of the vagina. The process of keratinization formed a sheet of strongly attached polygonal cells which lines the vagina. Moreover, the most striking conclusion from this study was the indication to the period of arrival of the neutrophils from the blood to the vaginal epithelium which lasts more than six hours. These observations indicate the importance of vitamin A in proliferation, keratinization and increase cellular immunity of the vagina.

\section{Introduction}

Vitamin A are alcohols and are therefore called retinols. It has a wide physiological and therapeutical roles, in growth, development and differentiation especially of cells and bones. The hormonal-like action of vitamin A can keeps the process of cellular differentiation (1).As it is known that the vaginal epithelium like other reproductive tissues is hormonal dependent, so that the height of the epithelium and the degree of keratinization vary with hormonal fluctuations during estrus cycle (2). It has a relation in immune response through $\mathrm{T}$-cell medicated responses. $(1,3,4 \& 5)$. ( $6 \& 7)$ stated that vitamin $\mathrm{A}$ acts as ligands in nuclear receptors in gap junctional of the adjacent cells and plays a role of morphogenesis, differentiation, hormonal secretion and growth. It also plays a role in carcinogenesis and teratogenesis. The deficiency of vitamin A affects the transport and storage of iron and then affect haematopoiesis (8). (9) confirms the presence of an enzymes in the mitochondria which control the production of energy, this enzymes were regulated by autonomic nervous system under the effect of vitamin A. In rats(10) found that vitamin A was important in spermatogenesis and prevent placenta necrosis and fetal resorption, moreover, vitamin A affects embryogenesis (11) and affects pituitary hormones formation(12). (13) revealed the wide care in vitamin A as a preventive of malignant cancers. The first promyelocytic leukemia has been treated by vitamin A (14). Besides, vitamin A was used in treatment of bronchopulmonory dyspnea (15) and pulmonary emphysema (16) and eye diseases (xerophthalmia) (13).(17\&18) revealed that vitamin A improved the function of rod cells of the retina in eye diseases. Additionally (19) stated that vitamin A controls the effect of enzymes used in the synthesis of glycoproteins and glycosaminoglycans which enter in the formation of the cells and tissues. This wide physiological and therapeutical roles of vitamin A leads to wide usage in drugs preparations, veterinary drugs and roughage and food addatives. From this point the random utilization phenomena of vitamin A was arise. The present study focused the light on the effect of vitamin A on the vaginal epithelium as there is little information about this respect and as the exfoliation have attracted great attention in recent years because of its relation to the immune defense. During estrus cycle, ewes present two different physiological behaviours i:e follicular and luteal phases according to the effect of estrogen and progesterone levels respectively (20) so that this study was designed to demonstrate 
the vaginal cytological effects of vitamin A

\section{Methods and Materials:}

This study was carried out in the animal house of the College of Veterinary Medicine, Baghdad University in 2009, using eight adult healthy Awassi sheep, and divided into two groups, the first group (treated group) gave (60.000) IU/animal of vitamin A once a week according to the method of (13), the second group left as a control group (non treated group). The diet of these animals was ad libitum in two periods (after morning and after noon). The water and minerals was provided in the animal house. The follicular and luteal

\section{Results and discussions:}

Table (1) referes that there was hypertrophy in the cells of the vaginal epithelium in both cyclic (estrus and luteal phases) and non cyclic animals in treated group. this may attributed to the accumulation of keratin and glycogen. This is similar to the findings of $(24 \& 25)$ who stated that as the vaginal epithelial cells move toward the superficial layers, they accumulated keratohyaline granules and glycogen in their cytoplasm, besides, (5, $26 \& 27)$ declaired that the glycogen was the prominent component of the vaginal epithelium. This is in accordance with (28 \& 29) who stated that the vaginal epithelial cells synthesize and accumulate glycogen as they migrate toward the surface. Moreover (30) in women, and $(31,32$ \& 33 ) in ewes found that the different vaginal cell types of Awassi sheep increased in size through their upward migration as keratin gradually occupies the cytoplasm instead of their organelles (Fig. 1) and even their nuclei (Fig. 2). On the other hand, under the influence of estrogen, the cells were filled with glycogen which have been converted into lactic acid by the endogenous bacteria. Lactic acid has a low $\mathrm{pH}$ where the pathogenic bacteria fail to live, so that the immune system was elevated. This is in agreement with the finding of (32 \& 34). Table (2) indicates the increase in the light cells (Fig. 3) especially in estrus phase of the treated group. This is similar to the finding of (30 $\& 35)$ in women who stated that under the phases have been recognized according to (21) depending on the estrus behaviours. Vaginal smears were prepared and stained by using methylene blue, the slides were examined under light microscope according to (22). Ocular oculometer was used for measuring the diameters of the vaginal epithelial cells. The data were calculated by using ANOVA test. The LSD was determine the statistical differences between the mean of the groups according to (23).

influence of estrogen, the percentage of light eosinophilic cells was elevated and the vaginal mucosa was loaded with starch and keratin, both giving the light discoloration to the cells. Table (3) revealed that there were increase in the percentage of small, medium-sized nuclei (Fig. 4) and nuclei-devoid cells on account of the large nuclei in the vitamin A-treated groups. This indicated that vitamin A stimulates firstly the mitotic divisions (hyperplasia) which in turn give rise to small cells with large nuclei responsible for protein synthesis, the keratin ( $31 \& 36)$. By the time and during its upward migration from the basal layer to the superficial layer the cells starting to enlarge and their nuclei going to decrease in size and finally the nuclei undergo apoptosis (Fig. 5) and then excluded from the cells which occupied completely by the keratin. A marked rise in mitotic rate was induced by glycogen (27, $28 \& 37)$. Table (4) refers to the increase in euchromatic nuclei (Fig. 6) in both estrus and luteal phases in the groups treated with vitamin $A$ as the euchromatic nuclei regarded as active chromatic which is related to protein synthesis. Mitosis give rise to small dark cells due to the very large number of free ribosomes in their cytoplasm with large dark nuclei which changed rapidly into pale nuclei as most of which were engaged in the synthesis of keratin through its upward migration to the surface of the epithelium. When the process of keratin synthesis was finished, 
these nuclei start to be small and pyknotic (apoptosis). (34) didn't refers to the role of light nuclei in protein synthesis (keratin). The present result was in accordance with (24 \& 26) who refers to the role of euchromatic cells during high metabolic activity.Table (5), Fig. (7) demonstrates clearly that there were significantly increase in the process of keratinization under the effect of vitamin A. this is in accordance with (26) who stated that vitamin A increase the permeability of the lysosomal membrane which aid in destruction of cellular organells and in variance with (37, $38 \& 39)$ who stated that the process of keratinization was inhibited and not affected by vitamin A.Table (6 and 7) revealed the absence of vacuolation and leukocytic infiltration respectively this may be attributed to the short period of both estrus and luteal phases which did not give enough time to those two phenomena to appear and reach the vaginal epithelium. (40) reported that leukocytes reach the vaginal epithelium after estrus, moreover the process of keratinization was a short process which lasted for many hours. (41) declaired that the period of moving of the vaginal epithelial cells from the basal layer to the surface of the vaginal epithelium takes only (2-6 hours). On the other hand leukocytes regarded as a strong evidence for recognition of estrus cycle in bitch due to the long period of estrus phase
(25).Table (8) explained the increase in folding of the cells with irregular outline (Fig. 8) in both estrus and luteal phases. Through its upward migration, the size of the vaginal cells increases and their shape changed from spherical to oval or even flattened polygonal, this extension in the surface area leads to the folding phenomena in their cell membranes as the junctional complexes and the bridges between them was going to disappear to be ready to exfoliation. This is reinforced by the statement of (42) who reported that as the vaginal cells of the basal layers move towards the surface, they become more flattened and more labile to folding. (33) reported that the exfoliated cells of the vagina take the folded shape to aid in expelling their nuclei.From the above observations, it can be concluded that vitamin $A$ has an important role in stimulation of the keratinization which regarded as an important process in immune defense of the vaginal epithelium, as the keratinized cells form a barrier of highly attached polygonal cells that prevent the penetration of any chemical, physical and microbial external factors (34). Besides it can be concluded for the first time that leukocytes need more than six hours to move from the blood capillaries to the site of vaginal epithelium as leukocytes were not detected through the process of keratinazation which take two to six hours.

Table (1): The effect of vitamin A supplement on cell size during different estrus phases.

\begin{tabular}{|c|c|c|c|c|c|c|}
\hline \multirow{2}{*}{$\begin{array}{l}\text { Cell size } \\
\text { Estrus } \\
\text { phases }\end{array}$} & \multicolumn{3}{|c|}{ Non treated group } & \multicolumn{3}{|c|}{ Treated group } \\
\hline & $\begin{array}{c}\text { Small } \\
(12-25) \\
\mu \mathrm{m}\end{array}$ & $\begin{array}{c}\text { Medium } \\
(30-50) \\
\mu \mathrm{m}\end{array}$ & $\begin{array}{c}\text { Large } \\
(50- \\
75) \mu \mathrm{m}\end{array}$ & $\begin{array}{c}\text { Small } \\
(12-25) \\
\mu \mathrm{m}\end{array}$ & $\begin{array}{c}\text { Medium } \\
(30-50) \\
\mu \mathrm{m}\end{array}$ & $\begin{array}{c}\text { Large } \\
(50- \\
75) \mu \mathrm{m}\end{array}$ \\
\hline Estrus & $\begin{array}{l}37 \\
\text { bf }\end{array}$ & $\begin{array}{l}39 \\
\text { bd }\end{array}$ & $\begin{array}{l}24 \\
\text { fh }\end{array}$ & $\begin{array}{l}25 \\
\text { eh }\end{array}$ & $\begin{array}{l}37 \\
\text { bf }\end{array}$ & $\begin{array}{l}38 \\
\text { be }\end{array}$ \\
\hline Luteal & $\begin{array}{l}33 \\
\mathrm{cg}\end{array}$ & $\begin{array}{l}43 \\
\mathrm{ac}\end{array}$ & $\begin{array}{l}24 \\
\text { fh }\end{array}$ & $\begin{array}{c}33.5 \\
\text { bf }\end{array}$ & $\begin{array}{c}19.75 \\
\text { gh }\end{array}$ & $\begin{array}{c}46.75 \\
a b\end{array}$ \\
\hline Non cyclic & $\begin{array}{c}56.17 \\
\mathrm{a}\end{array}$ & $\begin{array}{c}27.33 \\
\mathrm{dh}\end{array}$ & $\begin{array}{c}16.5 \\
h\end{array}$ & $\begin{array}{c}32.92 \\
\text { cg }\end{array}$ & $\begin{array}{c}25.5 \\
\mathrm{dh}\end{array}$ & $\begin{array}{c}41.58 \\
\text { bc }\end{array}$ \\
\hline
\end{tabular}

The numbers represented the percentage $\%$ of observation.

The small letters represented significant differences at $(\mathrm{P}<0.05)$. 
Table (2): The effect of vitamin A supplement on cytoplasm affinity for staining during different estrus phases.

\begin{tabular}{|c|c|c|c|c|}
\hline Cytoplasm affinity for staining & \multicolumn{2}{|c|}{ Non treated group } & \multicolumn{2}{|c|}{ Treated group } \\
\cline { 2 - 5 } Estrus phases & dark & light & dark & light \\
\hline \multirow{2}{*}{ Estrus } & 91 & 9 & 55.5 & 44.5 \\
& $\mathrm{a}$ & $\mathrm{a}$ & $\mathrm{a}$ & $\mathrm{a}$ \\
\hline \multirow{2}{*}{ Luteal } & 53 & 47 & 50 & 50 \\
& $\mathrm{a}$ & $\mathrm{a}$ & $\mathrm{a}$ & $\mathrm{a}$ \\
\hline \multirow{2}{*}{ Non cyclic } & 57 & 43 & 50.58 & 49.42 \\
& $\mathrm{a}$ & $\mathrm{a}$ & $\mathrm{a}$ & $\mathrm{a}$ \\
\hline
\end{tabular}

The numbers represented the percentage \% of observation.

The small letters represented no significant differences.

Table (3): The effect of vitamin A supplement on nuclear size during different estrus phases.

\begin{tabular}{|c|c|c|c|c|c|c|c|c|}
\hline \multirow{2}{*}{$\begin{array}{c}\text { Nucleus } \\
\text { size }\end{array}$} & \multicolumn{4}{|c|}{ Non treated group } & \multicolumn{4}{c|}{ Treated group } \\
\cline { 2 - 9 } $\begin{array}{l}\text { Estrus } \\
\text { phases }\end{array}$ & $\begin{array}{c}\text { Small } \\
(>7) \\
\mu \mathrm{m}\end{array}$ & $\begin{array}{c}\text { Medium } \\
(7-12.5) \\
\mu \mathrm{m}\end{array}$ & $\begin{array}{c}\text { Large } \\
(<12.5) \\
\mu \mathrm{m}\end{array}$ & $\begin{array}{c}\text { Without } \\
\text { nucleus }\end{array}$ & $\begin{array}{c}\text { Small } \\
(>7) \\
\mu \mathrm{m}\end{array}$ & $\begin{array}{c}\text { Medium } \\
(7-12.5) \\
\mu \mathrm{m}\end{array}$ & $\begin{array}{c}\text { Large } \\
(<12.5) \\
\mu \mathrm{m}\end{array}$ & $\begin{array}{c}\text { Without } \\
\text { nucleus }\end{array}$ \\
\hline \multirow{2}{*}{ Estrus } & $\begin{array}{c}1.5 \\
\mathrm{k}\end{array}$ & $\begin{array}{c}26 \\
\mathrm{di}\end{array}$ & $\begin{array}{c}54 \\
\mathrm{a}\end{array}$ & $\begin{array}{c}18.5 \\
\mathrm{ek}\end{array}$ & $\begin{array}{c}5.5 \\
\mathrm{jk}\end{array}$ & $\begin{array}{c}35 \\
\mathrm{be}\end{array}$ & $\begin{array}{c}19 \\
\mathrm{ek}\end{array}$ & $\begin{array}{c}40.5 \\
\mathrm{ad}\end{array}$ \\
\hline \multirow{2}{*}{ Luteal } & 6 & 33 & 47 & 14 & 8.5 & 20.75 & 22 \\
$\mathrm{jk}$ & $\mathrm{bf}$ & $\mathrm{ac}$ & $\mathrm{hk}$ & $\mathrm{ik}$ & $\mathrm{ej}$ & $\begin{array}{c}48.75 \\
\mathrm{ej}\end{array}$ & $\mathrm{ab}$ \\
\hline $\begin{array}{c}\text { Non } \\
\text { cyclic }\end{array}$ & 14 & $\begin{array}{c}29.33 \\
\mathrm{hk}\end{array}$ & $\begin{array}{c}41.17 \\
\mathrm{ch}\end{array}$ & $\begin{array}{c}15.5 \\
\mathrm{fk}\end{array}$ & $\begin{array}{c}14.42 \\
\mathrm{gk}\end{array}$ & $\begin{array}{c}33.5 \\
\mathrm{be}\end{array}$ & $\begin{array}{c}31.92 \\
\mathrm{bg}\end{array}$ & $\begin{array}{c}20.16 \\
\mathrm{ej}\end{array}$ \\
\hline
\end{tabular}

The numbers represented the percentage \% of observation.

The small letters represented significant differences at $(\mathrm{P}<0.01)$.

Table (4): The effect of vitamin A supplement on nucleus affinity for staining during different estrus phases.

\begin{tabular}{|c|c|c|c|c|}
\hline \multirow{2}{*}{ Nucleus affinity for staining } & \multicolumn{2}{|c|}{ Non treated group } & \multicolumn{2}{c|}{ Treated group } \\
\cline { 2 - 5 } Estrus phases & dark & light & dark & light \\
\hline \multirow{2}{*}{ Estrus } & 82.5 & 17.5 & 46.3 & 53.7 \\
& $\mathrm{a}$ & $\mathrm{a}$ & $\mathrm{a}$ & $\mathrm{a}$ \\
\hline \multirow{2}{*}{ Luteal } & 48 & 52 & 28.75 & 71.25 \\
& $\mathrm{a}$ & $\mathrm{a}$ & $\mathrm{a}$ & $\mathrm{a}$ \\
\hline \multirow{2}{*}{ Non cyclic } & 49.7 & 50.3 & 47.75 & 52.25 \\
& $\mathrm{a}$ & $\mathrm{a}$ & $\mathrm{a}$ & $\mathrm{a}$ \\
\hline
\end{tabular}

The numbers represented the percentage \% of observation.

The small letters represented no significant differences.

Table (5): The effect of vitamin A supplement on the keratinization during different estrus phases.

\begin{tabular}{|c|c|c|}
\hline $\begin{array}{c}\text { The groups } \\
\text { Estrus phases }\end{array}$ & Non treated group & Treated group \\
\hline \multirow{2}{*}{ Estrus } & $\begin{array}{c}34.5 \\
\mathrm{~b}\end{array}$ & $\begin{array}{c}75 \\
\mathrm{a}\end{array}$ \\
\hline \multirow{2}{*}{ Luteal } & $\begin{array}{c}18.5 \\
\mathrm{~b}\end{array}$ & $\begin{array}{c}76 \\
\mathrm{a}\end{array}$ \\
\hline \multirow{2}{*}{ Non cyclic } & $\begin{array}{c}45.5 \\
\mathrm{ab}\end{array}$ & $\begin{array}{c}43.1 \\
\mathrm{ab}\end{array}$ \\
\hline
\end{tabular}

The numbers represented the percentage $\%$ of observation.

The small letters represented significant differences at $(\mathrm{P}<0.05)$. 
Table (6): The effect of vitamin A supplement on the vaculation during different estrus phases.

\begin{tabular}{|c|c|c|}
\hline $\begin{array}{c}\text { The groups } \\
\text { Estrus phases }\end{array}$ & Non treated group & Treated group \\
\hline \multirow{2}{*}{ Estrus } & 1 & 0 \\
& $\mathrm{a}$ & $\mathrm{a}$ \\
\hline \multirow{2}{*}{ Luteal } & 3 & 3 \\
& $\mathrm{a}$ & $\mathrm{a}$ \\
\hline \multirow{2}{*}{ Non cyclic } & 1.3 & 6.92 \\
& $\mathrm{a}$ & $\mathrm{a}$ \\
\hline
\end{tabular}

The numbers represented the percentage \% of observation.

The small letters represented no significant differences.

Table (7): The effect of vitamin A supplement on the white blood cells during different estrus phases.

\begin{tabular}{|c|c|c|}
\hline $\begin{array}{r}\text { The groups } \\
\text { Estrus phases }\end{array}$ & Non treated group & Treated group \\
\hline Estrus & - & - \\
\hline Luteal & + & - \\
\hline Non cyclic & - & ++ \\
\hline
\end{tabular}

The numbers represented the presence observation.

Table (8): The effect of vitamin A supplement on the folding during different estrus phases.

\begin{tabular}{|c|c|c|}
\hline $\begin{array}{c}\text { The groups } \\
\text { Estrus phases }\end{array}$ & Non treated group & Treated group \\
\hline \multirow{2}{*}{ Estrus } & 5 & 12 \\
& $\mathrm{ac}$ & $\mathrm{a}$ \\
\hline \multirow{2}{*}{ Luteal } & 1 & 3 \\
& $\mathrm{c}$ & $\mathrm{bc}$ \\
\hline \multirow{2}{*}{ Non cyclic } & 2.5 & 9.58 \\
& $\mathrm{bc}$ & $\mathrm{ab}$ \\
\hline
\end{tabular}

The numbers represented the percentage $\%$ of observation.

The small letters represented significant differences at $(\mathrm{P}<0.05)$.

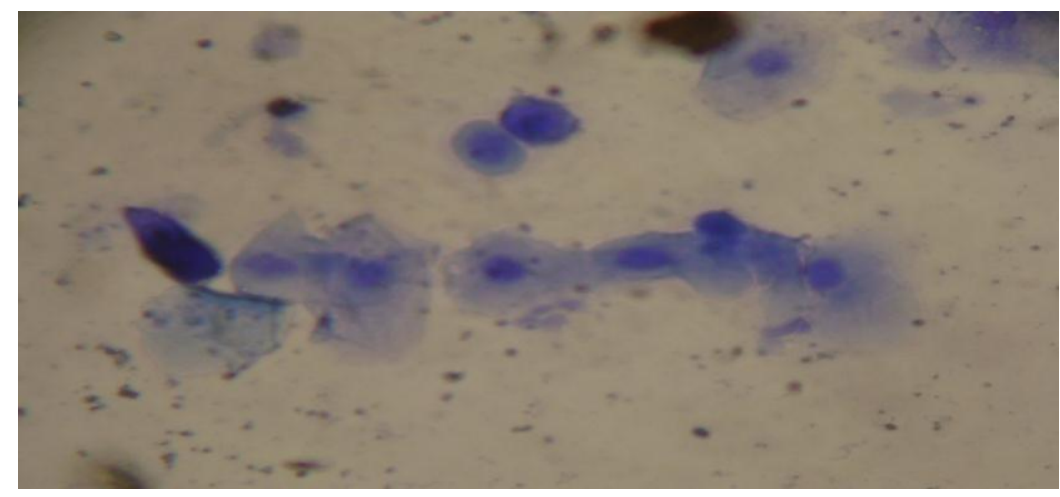

Fig. 1: Different sizes of vaginal epithelial cells. Keratin-filled cell

Methylene blue stain, 400X. 


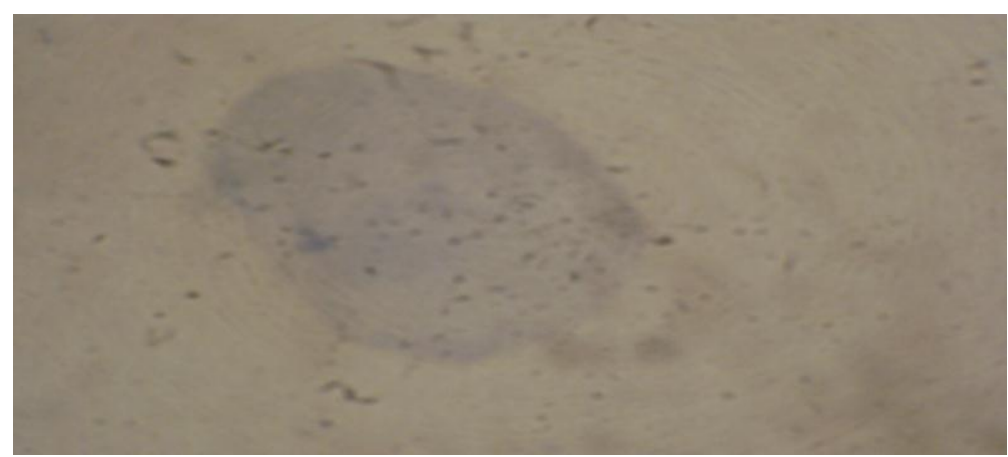

Fig. 2: Vaginal epithelial cell devoid of nucleus. Methylene blue stain, 400X.

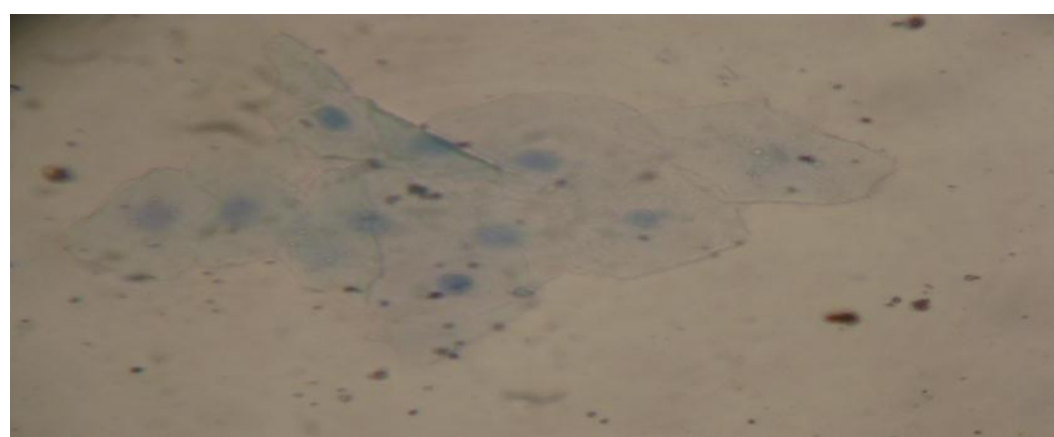

Fig. 3: Aggregation of light vaginal epithelial cells. Methylene blue stain, 400X.

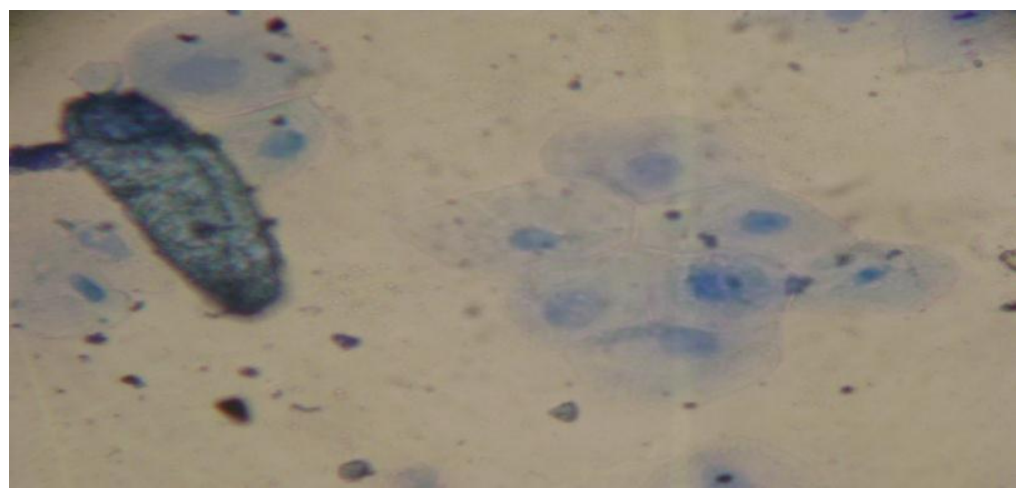

Fig. 4: Vaginal epithelial cells with different-sized nuclei. Methylene blue stain, 400X.

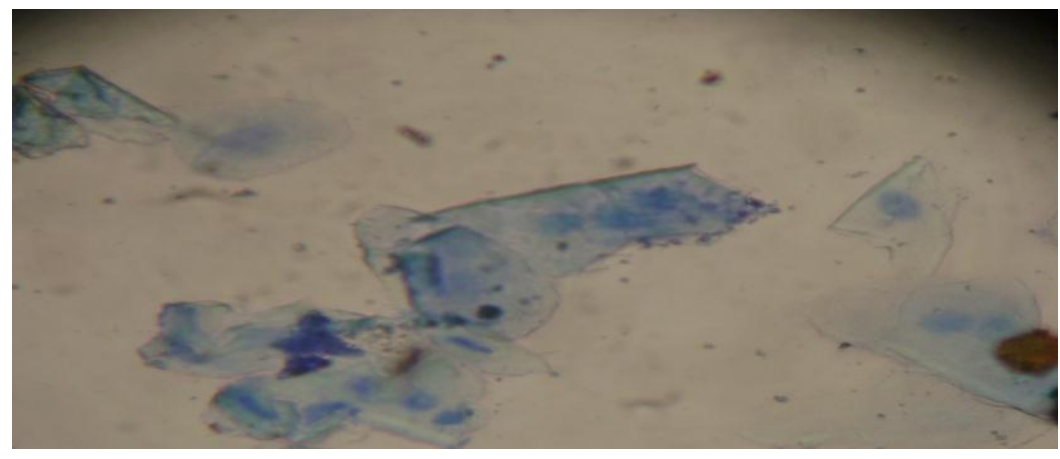

Fig. 5: Vaginal epithelial cell with apoptotic nucleus Methylene blue stain, 400X. 


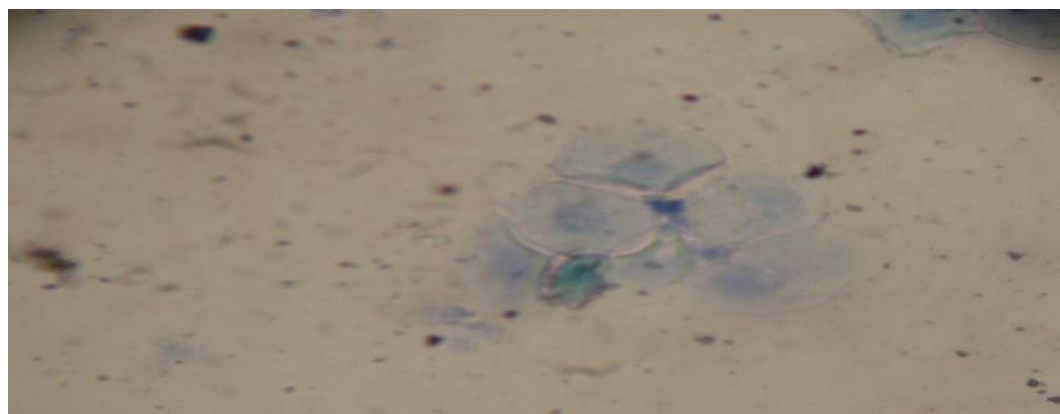

Fig. 6: Aggregation of vaginal epithelial cells with euchromatic nuclei.

Methylene blue stain, 400X.

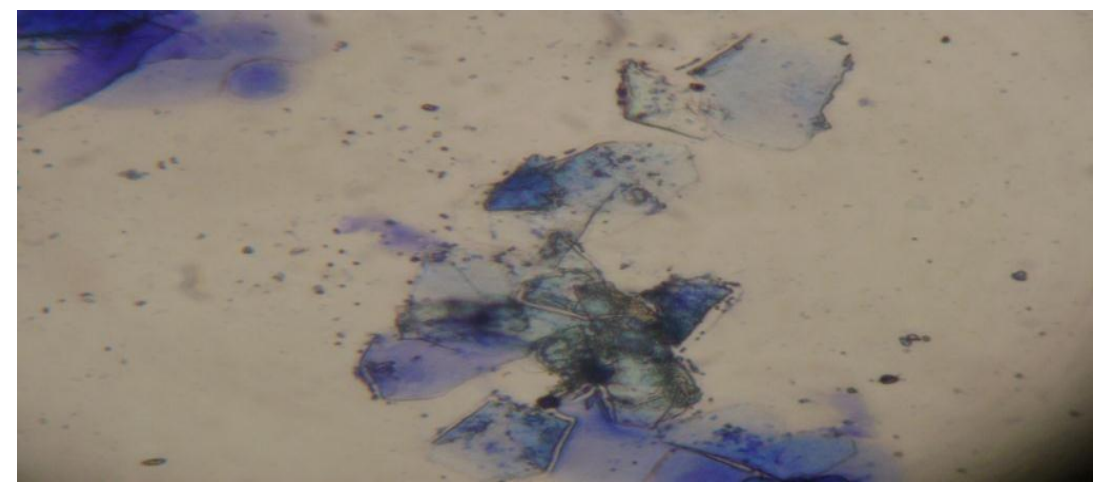

Fig. 7: Vaginal epithelial cells showing keratinization Methylene blue stain, 400X.

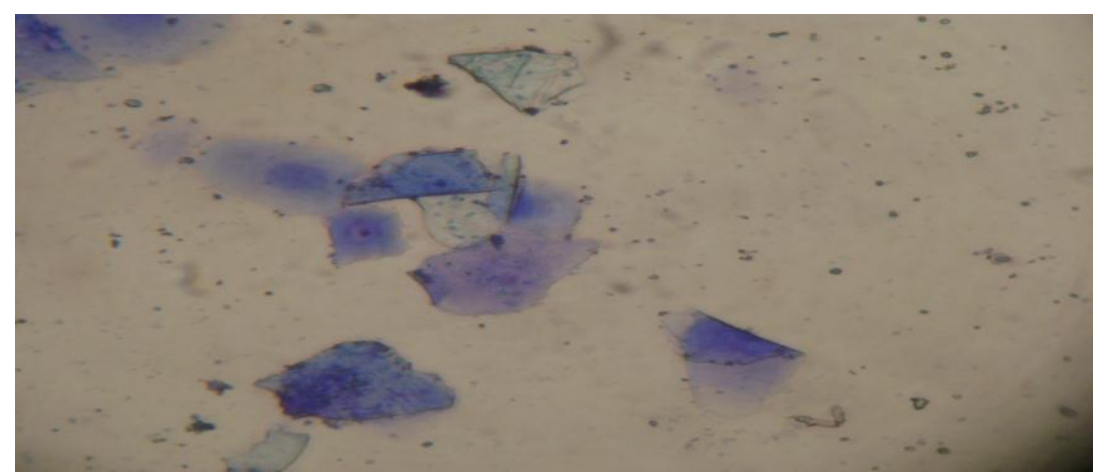

Fig. 8: Folding of the vaginal epithelial cells Methylene blue stain, 400X.

\section{References:}

1. Wolf G (1996). The regulation of retinoic acid formation. Nutr Rev, 54: 182-184.

2. Kwan PWL (2009). Female reproductive system. Tufts University School of Medicine, http://www.tusftsuniversityschool ofmedicine.org 7/3/2009.

3. Harber HA (1975). Review of Physiological Chemistry. $15^{\text {th }}$ ed. Middle East, London.

4. Semba RD, Motti $P$ and Chiphangwi JD (1998). Maternal vitamin A deficiency and infant mortality in Malwi. J Trop Pediatr, 44: 232234.

5. Ganong WF (2005). Review of Medical Physiology. $6^{\text {th }}$ ed. A Lange Medical Book. PP: 356380.

6. Djakoura C, Guibourdeche $\mathrm{J}$ and Porquet D (1986). Vitamin A and retinoic acid stimulate within minute CAMP release and growth hormone secretion in 
human pituitary cells. J Clin Endo Metab, 81: 3123-3126.

7. Stahl W and Sies H (1998). The role of carotenoids and retinoids in gap junctional communication. Int $\mathbf{J}$ Neut Res, 68: 358-359.

8. Sommer A and West KPJ (1996). Vitamin A deficiency health survival and vision. PP: 150-162. (cited by Al-Rekabi FMK 2002).

9. Alvarez R, De Andres J and Yubero P (1993). A novel regulatory pathway of brow fat thermogenesis. J Bio Chem, 270: 5666-5673.

10. Thompson JN, Howell JM and Pitt GA (1964). Vitamin A and reproduction in rat. Proc Roy Soc, 159: 510.

11. Ross AC (1999). Vitamins and retiniods. In: Modern nutrition in health and diseas. $19^{\text {th }}$ ed. (JA Meshils, M Olson, AC Shike and AC Ross). Williams and Wilkins, Baltimor.

12. Wolf G (1998). Vitamin A functions in the regulation of the dopaminergic system in the brain and pituitary gland. Nutr Rev, 56: 354-358.

13. Donald S, McLaren MD and Martin F (2001). Sight and life manual on vitamin A deficiency disorders. $2^{\text {nd }}$ ed. Switzerland.

14. Graf N, Riesinger $\mathrm{P}$ and Reinhard $\mathrm{H}$ (1995). Retinoids in the treatment of acute promyeol-cytic leukaemia. Klin Padiatr. 207(2): 43-47.

15. Shena JP (1999). Vitamin A supplementation in very low birth weight neonates: rationale and evidence. Pediatrics, 104: 13691374.

16. Massaro GD and Massaro D (1997). Retinoic acid treatment abrogates elastase-induced pulmonary emphysema in rats. Nature, 3: 675-677.

17. Berson EL, Rosner, B and Standberg MA (1993). A randomized trial of vitamin $A$ and vitamin $E$ supplementation of retinitis pigmentosa. Arch Opthalmol, 111: 761-772.

18. Berson EL (1999). Nutrition and retinal degenerations. In: Modern nutrition in health and disease. $9^{\text {th }}$ ed. (ME Shils, JA Olson, M Shike and ASS Ross). Williams and Wilkins, Baltimore, PP: 1491-1501.

19. Vahlquist A (1994). Role of retinoids in normal and diseased skin. In: Vitamin A in Health and Disease. Marcle Dekker, New York. P: 365-424.

20. Youngquist RS and Threlfall WR (2007). Large animal theriogenology. $2^{\text {nd }}$ ed. Saunders company.

21. Neama,H.F. (2000). Evaluation of reproductive performance of Awassi ewe lambs by using some hormonal programs. Master Thesis - Agriculture College Baghdad University.

22. Coles,E.N. (1986). Veterinary Clinical Pathology. $4^{\text {th }}$ Ed. W.B. Saunders Company, Philadelphia, USA.

23. Al-Mohammed NT, Al-Rawi KM, Younis MA and Al-Morani WK (1986). Principles of Statistics. Book House for Printing and Publishing. Al-Mousl University.

24. Dellmann HD and Brown EM (1976). Text book of Veterinary Histology. Lea and Febiger, Philadelephia. PP: 370-375.

25. Arthur GH Noakes DE Pearson H and Parkinson TJ (1996). Veterinary Reproduction and Obstetrics. $7^{\text {th }}$ ed. W.B. Sanuders Company.

26. Copenhaver WN, Vang RT and Bynge MV (1971). Bailye's Textbook of Histology. $16^{\text {th }}$ ed. Williams Company. PP: 62-182.

27. Lesson CR, Lesson TS and Paparo AA (1985). Textbook of Histology. 5th ed. Lg Aky Shoin Sandirs.

28. Ross MH, Romrell LJ and Kaye GI (1995). Histology. $3^{\text {rd }}$ ed. Williams and Wilkins Sydney. Tokyo. PP: 23-339. 
29. Gartner LP and Hiatt JL (2006). Color Atlas of Histology. $4^{\text {th }}$ ed. Lippincott Williams and Wilkins, PP: 193-194.

30. Dudek RW (2004). High Yield Histology. $3^{\text {rd }}$ ed. Lippincott Williams and Wilkins, Philadelphia. PP: 222-223.

31. Hussin AM (2006). The vaginal exfoliative cytology of Awassi ewes during post-parturient periods. Iraqi Journal Veterinary Medicine, 30(2): 130-137.

32. Zaid NW (2006). Effect of Prostaglandins F2 $\alpha$ on the Evaluation of Vaginal Epithelial Cells of Iraqi Ewes during Puerperium. Iraqi Journal Veterinary Medicine, 30 (2): 138144.

33. Hussin AM (2009). The theory of neutrophilic cellular penetration. Al-Anbar J Vet Sci, 2(1):58-68.

34. Hussin AM (2010). The theory of keratinization. Unpublished paper.

35. Junqueria LC and Carneiro J (2009). Basic Histology Text Atlas. 11 ${ }^{\text {th }}$ ed.

www.mk:@msitstore:h:basic\%20 histology. 23/5/2009.

36. Junqueira LC, Carneiro $\mathrm{J}$ and Kelley,R.O. (2003). Basic

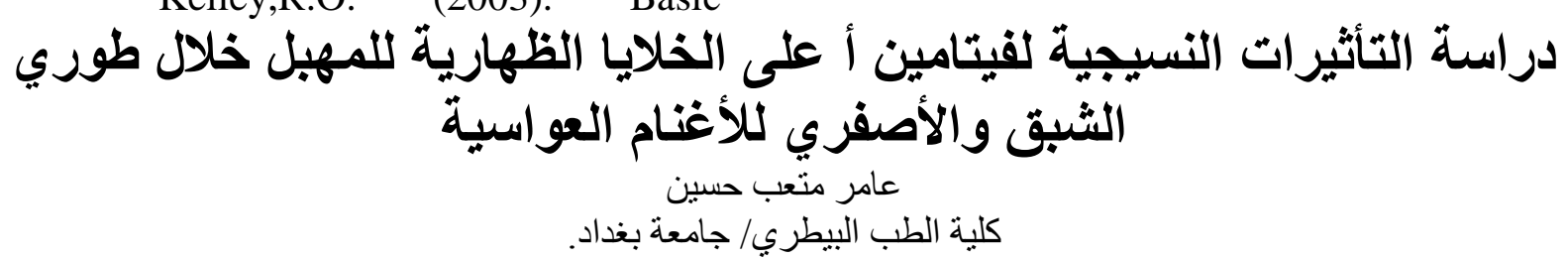

Histology. $10^{\text {th }}$ ed. A Lange Medical Book. PP: 28-104.

37. Breazile JE (1971). Textbook of Veterinary Physiology. Lea and Febiger, Philadelphia, USA. PP: 214-308.

38. Takasugi N (1967). Effects of Vitamin A on Vaginal Epithelium Showing Estrogen-Independent Cornification in Neonatally Estrogenized Mice. Proceedings of the Japan Academy, 43(6): 511-516.

39. Zaid NW (2010). The effect of vitamin A supplement on the vaginal epithelium during pregnancy months and post parturition. Unpublished paper.

40. Al-Wahab RMH (1977). Determination of puberty and the possibility of successful pregnancy and lambing in pubertal ewe lambs. $4^{\text {th }}$ Sci Conven Iraqi Biol Soci, PP: 114-117.

41. Ross MH, Romrell LJ and Kaye GI (1999). Histology. $4^{\text {th }}$ ed. Williams and Wilkins, Sydney, PP: 374-375.

42. Dellman HD and Brown EM (1994). Textbook of veterinary histology. Lea and Febiger, Philadelphia.

\footnotetext{
الخلاصة

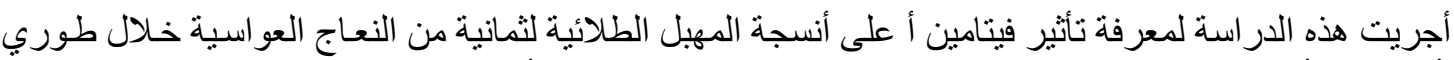

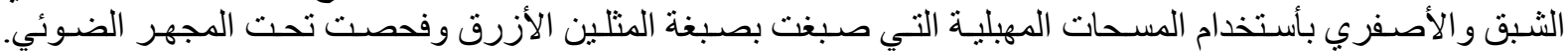

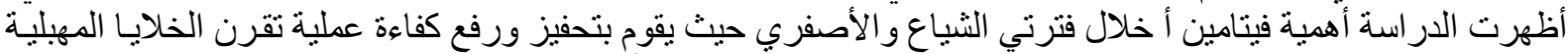

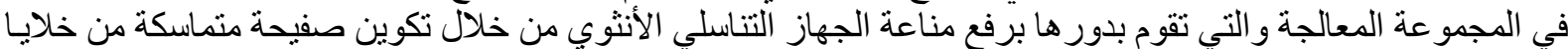

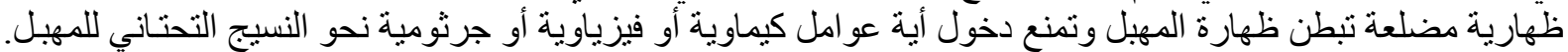

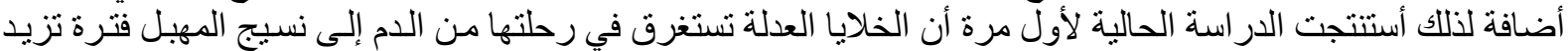

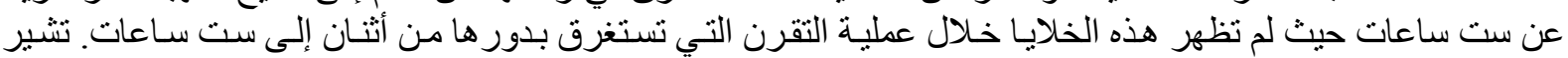
التنائج أعلاه إلى أهمية فيتامين أ في تحفيز التكاثر الخلوي و التقرن وزية التيادة المناعة الخلوية لنسيج المهيل.
} 